\title{
STUDIES IN TUBERCULOSIS IN HONG KONG
}

\author{
By K. H. UTTLEY, M.A., M.D., D.T.M. AND H. \\ Medical Officer, Hong Kong
}

(With 2 Graphs in the Text)

INTRODUCTION

THE purpose of these papers was:

(i) To ascertain the standardized death-rates for tuberculosis among the urban Chinese of Hong Kong.

(ii) To review the more important articles dealing with tuberculosis among the Chinese.

(iii) To compare the data obtained in (ii) with those found in this survey of urban Chinese in Hong Kong.

The material to be discussed will appear under the following headings:

(a) Tuberculosis, all forms.

(b) Pulmonary tuberculosis.

(c) Miliary tuberculosis.

(d) Abdominal turberculosis.

(e) Tuberculosis of the nervous system.

( $f$ ) Remaining forms of tuberculosis.

This work was stimulated by the desire to find out what is the mortality from tuberculosis among the Chinese. Nowhere in China are there any data by which to estimate even roughly what is the death-rate from this disease among the population. It was felt that as death returns have been compulsory for many years in Hong Kong, it would be possible to calculate the standardized death-rates for the Chinese in the city, and thereby make a useful contribution to that little which is so far known about Chinese mortality rates.

Even in England there are no accurate figures available about the incidence of tuberculosis. "The mortality figures are a...trustworthy guide, and in almost all cases the incidence of the disease has had to be measured by its death-rate. If it is found that the mortality from tuberculosis is declining, it is justifiable to assume in dealing with so fatal a disease that its incidence is also declining" (MacNalty, 1932, p. 5).

So many claims are made by doctors and others in the East that the disease is increasing at an alarming rate among the indigenous population, or else that its incidence remains unchanged, claims that are based on little or no evidence, that $I$ hope the data contained in this series of papers may help in the formation of a more reasoned opinion on the matter.

Anyone who has worked in the East or in the tropics will know how difficult it is in such countries to get accurate information on scientific matters, and this 
seems to be especially so in the cases of epidemiology. Errors in diagnosis, slackness in investigation and in making returns, insufficiently trained personnel, and even wilful misstatements all militate against accuracy.

As regards inaccuracy in death returns, though it is undeniable that diagnoses are too often made on evidence that is faulty or incomplete, the figures dealing with the urban Chinese of this Colony are probably more accurate than most places in the tropics for the following reasons:

(a) The Colony is small and supervision is to that extent better than it is in larger places.

(b) No corpse can be buried without the death first being registered, this registration being granted only on the receipt of a western-trained doctor's certificate of the cause of death, or in special cases it may be granted by a European magistrate after investigation.

(c) It is not the custom in Hong Kong, a custom prevalent in certain tropical countries, for the village headman or native policeman to sign certificates of death.

(d) All death certificates are scrutinized by the Medical Officer of Health.

The diagnosis of the cause of death rests in the majority of cases with the general practitioner. Sputum or X-ray diagnosis is almost restricted to the hospitals. (There are rather more than one bed to 600 persons. At the last census there was one doctor to 2600 of the population.) There is as yet little dread of the word "tuberculosis" among the poor, so there is no incentive on the part of the doctor to have a case signed up as bronchitis or some other complaint out of consideration for his patient.

All the same, the material contained in this series of papers must be considered as being an approximation to the truth. It has not the accuracy of similar figures dealing with western Europe or North America, but they are the only figures so far available dealing with tuberculosis death-rates among urban Chinese in Asia. It is for this reason, if for no other, that I wish to publish them.

This study begins with the year 1920, covers the next 15 years, and analyses 34,782 tuberculosis deaths. It did not start at an earlier date, because an examination of the death returns showed that prior to 1920 statistics were not accurate enough for my purpose. Another reason was that by then there were enough Chinese medical graduates of Hong Kong University in private practice to make it a fair assumption that there was some degree of accuracy in the death returns so far as the urban Chinese were concerned. A further reason was that by then the law relating to the registration of deaths had been in force for many years and people understood the routine involved.

During this survey I have personally scrutinized every entry in the death registers during the period under review, the number exceeding 227,000 , and catalogued each death from tuberculosis according to the age, sex, month of death of the deceased, and locality of death. It deals only with urban Chinese; all deaths among the rural or boat population, temporary residents' or non- 
Chinese deaths have been excluded. Unfortunately it was not found possible to investigate the mortality according to occupation, because it was only two years ago, as a result of this investigation, that the occupation of the deceased had to be entered on every return.

\section{Geography and climate of Hong Kong}

Hong Kong consists of approximately 300 square miles of territory. The Island of Hong Kong comprises 32 square miles, on which is the city of Victoria, usually called Hong Kong. It is separated by the harbour from the peninsula and city of Kowloon, behind which is the mainland of the Colony, with numerous islands. The harbour is $\frac{3}{4}$ mile across at its narrowest point.

The Colony is situated at the mouth of the river on which stands Canton, 90 miles from Hong Kong. It consists of a series of granite ridges separated by narrow valleys where a certain amount of rice and vegetable produce is grown. There is very little level land.

Being situated just within the tropics, and on the sea immediately south of the great landmass of China, its climate is much influenced by the monsoons. The north-east monsoon prevails from November to April, when the weather is cool, refreshing and dry. The south-west monsoon blows from May to October, when the conditions are those associated with hot, damp, muggy and enervating weather. During the winter months the temperature ranges from 45 to $70^{\circ} \mathrm{F}$. with an average of about $65^{\circ}$; in summer the thermometer stands at $87^{\circ} \mathrm{F}$. with little variation day or night. The relative humidity is constantly between 80 and $90 \%$ saturation in the summer, and from 68 to $80 \%$ in the winter. The rainfall averages $85 \frac{1}{2}$ in., and most of the rain falls in the summer.

\section{Population}

Hong Kong depends for its existence and prosperity on the entrepot trade with South China, and 70-80\% of its population live in the two cities of Victoria and Kowloon, which may be considered as one city, separated by the harbour. The total civil population of the Colony, $97 \%$ of which are Chinese, is about 900,000; of these 400,000 live in Victoria, 300,000 in Kowloon, 100,000 in the villages of the mainland and on the islands, and 100,000 in small boats on the harbour. At the last census only $30 \%$ claimed to have been born in the Colony. The urban population at the last two censuses was:

$\begin{array}{cccc}\text { Year } & \text { Males } & \text { Females } & \text { Total } \\ 1921 & 271,090 & 161,560 & 432,650 \\ 1931 & 370,903 & 266,800 & 637,703\end{array}$

It is estimated that about 7000 people arrive in and about the same number depart from the Colony every day, travelling by rail, steamer, junk or sampan. They come from the neighbouring provinces of China, but mainly from $\mathrm{K}$ wangtung. The ease with which the border may be crossed makes it impossible to have accurate checking of these figures, so that except for census years there are no accurate statistics available. 


\section{Housing and sanitary conditions}

The two cities of Victoria and Kowloon are widely different. The former is old-fashioned in its planning, and is greatly overcrowded. The latter is modern and well laid out. ${ }^{1}$

Victoria stands on a narrow strip of land, 4 miles long by from $\frac{1}{5}$ to $\frac{2}{5}$ mile broad, lying between the hills and the sea, and with a total area of 1 square mile. Parts of the town totalling 200 acres have a population of 200,000 , being a density of 1000 to the acre (Wellington, 1933a). This scarcity of building land and the extreme congestion have resulted in high land values, so that houses have been built normally of four and five stories high. Sometimes the height of the buildings is five times the width of the streets, which are seldom wider than $22 \mathrm{ft}$. Any newcomers to the city have to squeeze into these already overcrowded houses. A typical house consists of a 15 or $17 \mathrm{ft}$. frontage and extends back from the street for about $50 \mathrm{ft}$. The front half of the ground floor will be a shop, the back half and all the other floors will be residential quarters. These consist of a corridor down one side, with cubicles down the other, and a common kitchen on each floor at the back. Each cubicle will house a family, and a floor may contain any number of people up to fifty or so. A wooden stairway connects each floor with the next. The only windows are at the front and back. They are usually kept shut, and even the blinds are drawn, so that a minimum of light and air can enter. It is evident that here are all the factors making for squalor, overcrowding, slums and insanitary conditions.

Kowloon has been planned on up-to-date lines, as it is a much newer city, and there is much more space there than in Hong Kong. It is rapidly increasing in size, and will soon surpass the senior city in this respect. At the last census there were 300 people to the acre.

In the Colony "there are no estates, plantations or mines, and comparatively few large factories. The majority of the urban labouring classes are engaged in matters connected with commerce, shipping or public works, and the bulk of the remainder find employment in shops, workshops or independent businesses. There is no need for recruitment of labour, the supply being sufficient to satisfy all demands" (Wellington, 1933b), and this is so, although a committee which recently investigated the matter, found that the average monthly wage of this coolie class was about $\$ 4.50$ per person. (The local dollar fluctuates with the price of silver, but recently it has been steady at an exchange rate of $14 \frac{1}{2}-15 d$.)

Certain factors tend to upset the sex and age distribution of this urban population. First there is the daily coming and going of 7000 persons, mainly young adult and middle-aged males. Secondly, many married people send their children when aged about 5 years to the ancestral village to live with the grandparents. This is partly for economy, and partly because of the congestion in the

1 It is a pity that at the census the two cities were not fully separated statistically, because in that case it would have been possible for these papers to have dealt fully with the different rates in the two cities, which I cannot do owing to the way in which the census report was made out. 
city. The children return when they are of an age to earn or to be married off, i.e. in their late teens. This homing instinct shows itself also in the fact that when illness befalls them, the sick endeavour to return to their native village. Women can do this more easily than men; the latter cannot afford to leave their work, or they put it off until it is too late. To what extent this affects the death returns it is impossible to say.

The male element predominates over the female in the two cities. It will be seen later that this predominance was less in 1931 than it was in 1921. Most of the women are married; in China the unattached female is very uncommon. The wife comes to Hong Kong as soon as the husband has found a post which he considers reasonably secure, they occupy one of the tenements already described, sharing the available floor space with several other families. All the occupants of the floor have meals in common. They share ricebowls and chopsticks, and spit freely on the floor on which their infants and children are crawling. Mothers frequently chew their babies' food before inserting it into their mouths.

It will be seen then that when the Chinese come to Hong Kong they come from the outdoor occupations of village life to take up an indoor one, where they live under very overcrowded conditions. Wages being very low, the vast majority of the population live perilously near the starvation line; their diet is deficient in iron, calcium, vitamins and good quality food. When they fall ill, they tend to have the disease in a more severe form than a European would. Under these circumstances it is not surprising if the mortality from tuberculosis is much higher than it is in Europe.

These conditions apply to the urban Chinese of the Colony, they do not apply to the rural areas, even though the countryside may be as poor as the town. I have had some experience of medical work in the villages, and I can state without any hesitation that though tuberculosis is present there, it is not present in anything like the high incidence of the city. I consider, moreover, that this would be true of village life throughout China.

The housing conditions described above must be taken into consideration when analysing the figures to be given later. It is essential to remember that many, if not all, of them play a part in statistics from all tropical countries, they are not necessarily peculiar to Hong Kong. Everywhere throughout the tropics it is the same story of the poor man coming from the countryside where there is less tuberculosis, to the cities and towns to live in overcrowded conditions, where tuberculosis abounds.

In comparing conditions in Kong Kong with those elsewhere in China, there is probably little difference, except that in the former they are a little better. All Chinese cities have a preponderance of young adult males living crowded together, who come to the towns to earn a livelihood, only to return to the country later. Observers when discussing the incidence of tuberculosis in China, have drawn attention to this similarity in the conditions of the cities of the Colony with those of China; for instance, Bume (1934) says, "the incidence 
of tuberculosis in China cannot be very different from that in Hong Kong...'. From a statistical point of view it will be seen that a fairly large minority of the population has never at any time been resident in the Colony for long, that probably many who contract diseases return to their native villages before dying, and that this probably occurs to a greater extent among females than among males.

\section{TUBERCULOSIS, ALL FORMS}

This section will deal first with death-rates for tuberculosis, all forms, in the urban areas of Hong Kong; it will then review the more important articles which have appeared recently on the incidence of the disease in China, and will finally compare the data so obtained with what occurs in Hong Kong.

Although in the first instance an attempt was made to calculate standardized death-rates for Hong Kong for each individual year beginning at 1920, in the final stages only the rates for the two census years 1921 and 1931 were retained. These were calculated by the direct method of standardization and are based on the England and Wales 1901 population. For the census years the age grouping of the population is known and the direct method is applicable. For the intercensal years where the numbers of the population in specific age groups are not known one would generally be safe in employing the indirect method of standardization. But even this assumes a constancy in the age distribution of the population from one census to the next. Such an assumption in regard to Hong Kong with its highly fluctuating and migratory population is clearly inadmissible, and the standardized death-rates for the intercensal years were therefore discarded.

Table I gives the standardized death-rates for tuberculosis, all forms, for Hong Kong, with similar rates for England and Wales for comparison.

Table I. Standardized death-rates from tuberculosis (all forms) per million living for the years 1921 and 1931

\begin{tabular}{lcccc} 
Year & \multicolumn{3}{c}{ Hong Kong } & $\begin{array}{c}\text { England and } \\
\text { Wales } \\
\text { Persons }\end{array}$ \\
1921 & Males & Females & Persons & 1117 \\
1931 & 4014 & 4581 & 4297 & 869
\end{tabular}

The mortality is extremely high, about four times as great as in England and Wales at 1921 and five times as great in 1931. Whereas the English figures are appreciably less in the later year, the Hong Kong figures show no signs of improvement. This indicates that the population has not yet adjusted itself to city life, and succumbs to tuberculosis in a large number of cases.

To use the ratio of deaths from tuberculosis to deaths from all causes is to expose oneself to criticism on the score of the results being misleading owing to variations in the mortalities of different diseases, but where statistics are so few as in the Far East, it is justifiable to glean such information as is possible from what exists. Therefore Table II shows the ratio of tuberculosis deaths to 
those from all causes, grouped for age and sex, for the years 1921 and 1931. In comparing the years 1921 and 1931 with the English figures, the large incidence in children under 5 years of age, some three times as much in 1921 and twice as much in 1931 as in England and Wales in 1929 is very noticeable. The relative incidence has lessened somewhat in the next decade up to puberty. During the

Table II. Ratio of deaths from tuberculosis to those from all causes, grouped according to age and sex. Census years 1921 and 1931. (England and Wales data for 1929 given for comparison)

\begin{tabular}{|c|c|c|c|c|c|c|c|c|}
\hline \multirow[b]{2}{*}{ Age } & \multicolumn{4}{|c|}{ Males } & \multicolumn{4}{|c|}{ Females } \\
\hline & $\begin{array}{l}\text { Total } \\
\text { no. of } \\
\text { deaths }\end{array}$ & $\begin{array}{c}\text { Tubercu- } \\
\text { losis } \\
\text { deaths }\end{array}$ & $\begin{array}{c}\text { o of } \\
\text { total } \\
\text { deaths }\end{array}$ & S.D. of $\%$ & $\begin{array}{l}\text { Total } \\
\text { no. of } \\
\text { deaths }\end{array}$ & $\begin{array}{c}\text { Tubercu- } \\
\text { losis } \\
\text { deaths }\end{array}$ & $\begin{array}{l}\text { \% of } \\
\text { total } \\
\text { deaths }\end{array}$ & S.D. of $\%$ \\
\hline $\begin{array}{c}0- \\
5- \\
15- \\
25- \\
35- \\
45- \\
55- \\
65-\end{array}$ & $\begin{array}{r}2,663 \\
249 \\
405 \\
598 \\
646 \\
505 \\
387 \\
322\end{array}$ & $\begin{array}{r}239 \\
64 \\
85 \\
167 \\
196 \\
104 \\
57 \\
14\end{array}$ & $\begin{array}{r}8 \cdot 97 \\
25 \cdot 70 \\
20 \cdot 99 \\
27 \cdot 93 \\
30 \cdot 34 \\
20 \cdot 59 \\
14 \cdot 73 \\
4 \cdot 35\end{array}$ & $\begin{array}{l}1921 \\
0 \cdot 55 \\
2 \cdot 77 \\
2 \cdot 02 \\
1 \cdot 83 \\
1 \cdot 80 \\
1 \cdot 80 \\
1 \cdot 80 \\
1 \cdot 14\end{array}$ & $\begin{array}{r}2,806 \\
360 \\
207 \\
288 \\
266 \\
182 \\
165 \\
244\end{array}$ & $\begin{array}{r}287 \\
93 \\
60 \\
123 \\
86 \\
49 \\
15 \\
8\end{array}$ & $\begin{array}{r}10 \cdot 23 \\
25 \cdot 83 \\
28 \cdot 99 \\
42 \cdot 71 \\
32 \cdot 33 \\
26 \cdot 92 \\
9 \cdot 09 \\
3 \cdot 28\end{array}$ & $\begin{array}{l}0 \cdot 57 \\
2 \cdot 31 \\
3 \cdot 15 \\
2 \cdot 91 \\
2 \cdot 87 \\
3 \cdot 28 \\
2 \cdot 24 \\
1 \cdot 14\end{array}$ \\
\hline Total & 5,775 & 926 & $16 \cdot 03$ & $0 \cdot 48$ & 4,518 & 721 & $15 \cdot 96$ & 0.54 \\
\hline $\begin{array}{c}0- \\
5- \\
15- \\
25- \\
35- \\
45- \\
55- \\
65-\end{array}$ & $\begin{array}{r}5,463 \\
422 \\
685 \\
1,007 \\
994 \\
953 \\
850 \\
592\end{array}$ & $\begin{array}{r}342 \\
91 \\
163 \\
293 \\
270 \\
211 \\
117 \\
23 \\
\end{array}$ & $\begin{array}{r}6 \cdot 26 \\
21 \cdot 56 \\
23 \cdot 80 \\
29 \cdot 09 \\
27 \cdot 16 \\
22 \cdot 14 \\
13 \cdot 76 \\
3 \cdot 89\end{array}$ & $\begin{array}{l}1931 \\
0 \cdot 33 \\
2 \cdot 00 \\
1 \cdot 62 \\
1 \cdot 43 \\
1 \cdot 41 \\
1 \cdot 34 \\
1 \cdot 18 \\
0 \cdot 79\end{array}$ & $\begin{array}{r}5,516 \\
427 \\
394 \\
566 \\
415 \\
\mathbf{3 8 1} \\
\mathbf{3 8 7} \\
592\end{array}$ & $\begin{array}{r}410 \\
76 \\
127 \\
172 \\
131 \\
83 \\
41 \\
17\end{array}$ & $\begin{array}{r}7 \cdot 43 \\
17 \cdot 80 \\
32 \cdot 23 \\
30 \cdot 39 \\
31 \cdot 57 \\
21 \cdot 78 \\
10 \cdot 59 \\
2 \cdot 87\end{array}$ & $\begin{array}{l}0.35 \\
1 \cdot 85 \\
2 \cdot 35 \\
1.93 \\
2 \cdot 28 \\
2 \cdot 12 \\
1 \cdot 56 \\
0 \cdot 68\end{array}$ \\
\hline Total & 10,966 & 1,510 & $13 \cdot 77$ & $0 \cdot 33$ & 8,687 & 1,057 & $12 \cdot 18$ & $0 \cdot 35$ \\
\hline $\begin{array}{c}0- \\
5- \\
15- \\
25- \\
35- \\
45- \\
55- \\
65-\end{array}$ & $\begin{array}{r}41,304 \\
7,392 \\
10,657 \\
11,271 \\
16,694 \\
29,478 \\
44,410 \\
108,697\end{array}$ & $\begin{array}{r}1,469 \\
970 \\
3,560 \\
3,734 \\
3,926 \\
4,149 \\
2,487 \\
991\end{array}$ & $\begin{array}{r}\text { Eng } \\
3.56 \\
13 \cdot 12 \\
33 \cdot 40 \\
33 \cdot 13 \\
23 \cdot 52 \\
14 \cdot 07 \\
5 \cdot 60 \\
0.91\end{array}$ & $\begin{array}{l}0.09 \\
0 \cdot 39 \\
0 \cdot 46 \\
0 \cdot 44 \\
0 \cdot 33 \\
0 \cdot 20 \\
0 \cdot 11 \\
0 \cdot 03\end{array}$ & $\begin{array}{r}33,193 \\
6,635 \\
9,965 \\
11,425 \\
14,399 \\
23,375 \\
36,662 \\
126,935\end{array}$ & $\begin{array}{r}1,171 \\
1,095 \\
4,646 \\
3,861 \\
2,477 \\
1,746 \\
1,057 \\
651\end{array}$ & $\begin{array}{r}3 \cdot 53 \\
16 \cdot 50 \\
46 \cdot 62 \\
33 \cdot 79 \\
17 \cdot 20 \\
7 \cdot 47 \\
2 \cdot 88 \\
0 \cdot 51\end{array}$ & $\begin{array}{l}0 \cdot 10 \\
0.46 \\
0.50 \\
0 \cdot 49 \\
0 \cdot 31 \\
0 \cdot 17 \\
0 \cdot 09 \\
0.02\end{array}$ \\
\hline Total & 99,903 & 21,286 & $7 \cdot 89$ & 0.05 & 262,589 & 16,704 & $6 \cdot 36$ & 0.04 \\
\hline
\end{tabular}

decade 15-24 the ratio is considerably less than in England, due in my opinion to the constant arrival of non-infected people from the country. In the decade 25-34, the ratio compared with British figures is rather less, except for females in 1921 , when $42.7 \%$ of all deaths were due to tuberculosis. From the age of 35 onwards the ratio is consistently higher than in England.

In comparing the two census years with each other, there has been a decline in the ratio as a whole, though at 15-24, and in males from 25-34 and 45-54, there was a slight rise in 1931. There was also a slight rise in the 1931 female 
ratio at the age 55-64. In $193125 \%$ of all deaths between 15 and 34 in males and $31 \%$ of those in females were caused by tuberculosis. This is a lower ratio than in Britain; MacNalty (1932, p. 5) when discussing some recent English figures states that at this age approximately one-third of the deaths in males, and one-half of those in females are due to tuberculosis. Taking all ages into consideration, the ratio of tuberculosis deaths to those from all causes is twice as high in Hong Kong as in England. This incidence in Hong Kong for 1921 is about the same as it was in England and Wales in the 'fifties of last century, when the ratio was about $16.4 \%$, whereas that for 1931 resembles what was happening in the 'seventies, when the figure was $14 \%$. This decline, however, is liable to give a false impression of what is happening, because the change appears to be due almost entirely to a fall in infancy and childhood. The adult rate during the two census years showed a tendency to rise, as will be seen in Table III. There is not enough information available to argue that the rise and

Table III. Mortality from tuberculosis in 1931, expressed as a percentage of that of 1921

\begin{tabular}{|c|c|c|c|}
\hline Age & Males & Females & Persons \\
\hline 0 & 90 & 87 & 88 \\
\hline $5-$ & 93 & 49 & 66 \\
\hline $10-$ & 81 & 100 & 89 \\
\hline 15 & 96 & 117 & 111 \\
\hline 20 & 175 & 125 & 157 \\
\hline $25-$ & 145 & 82 & 117 \\
\hline $35-$ & 116 & 90 & 106 \\
\hline $45-$ & 145 & 85 & 121 \\
\hline $55-$ & 117 & 126 & 121 \\
\hline 65- & 137 & 111 & 123 \\
\hline 75- & 101 & - & 44 \\
\hline ude rate all ages $\ldots$ & 124 & 87 & $\begin{array}{r}107 \\
08\end{array}$ \\
\hline andardized rate all ages & 112 & 87 & 98 \\
\hline
\end{tabular}

fall were continuous throughout the decade. The rise in the adult male mortality is probably due to the increasing congestion of the cities; it is possible that the decline in the adult female rate may be due to the arrival in the Colony in increasing numbers of new and healthy wives, but it is not possible to give a satisfactory explanation for this decline. It is reasonable to infer, however, that though the female population has risen proportionately faster than the male (see population figures in the first section), the female tuberculosis rate has fallen, while that for males has risen.

Table IV shows the death-rate from all forms of tuberculosis expressed as a percentage of deaths from all causes for each of the years investigated. There is a rise in 1927, which continues until 1929; a rise is seen also in Table I and in other tables following in this paper. Some of the reasons which caused this rise in Table I have already been discussed. This is the place to consider another factor which influences more particularly the variations seen in Table IV, and this is, the effect of epidemics of diseases such as plague and smallpox on the rate of tuberculosis deaths relative to deaths from all causes. The years 1922-4 witnessed epidemics of both these diseases, which caused a large number of 
deaths in the general population, and a consequent fall in the percentage figures in Table IV. In 1925 there was the general strike with a great exodus of Chinese from the Colony as already described. Population estimates for 1925 and 1926 are admittedly mere guesses. In 1931 and 1932 there were many deaths among infants from bronchopneumonia. There is thus a considerable Table IV. Deaths from tuberculosis, expressed as a percentage

\begin{tabular}{lcrc} 
& \multicolumn{2}{c}{ of deaths from all causes } & \\
Year & $\%$ & Year & $\%$ \\
1920 & $16 \cdot 1$ & 1928 & $18 \cdot 8$ \\
1921 & $16 \cdot 0$ & 1929 & $18 \cdot 3$ \\
1922 & $13 \cdot 7$ & 1930 & $15 \cdot 0$ \\
1923 & $13 \cdot 2$ & 1931 & $13 \cdot 1$ \\
1924 & $15 \cdot 1$ & 1932 & $14 \cdot 1$ \\
1925 & $14 \cdot 7$ & 1933 & $16 \cdot 7$ \\
1926 & $14 \cdot 9$ & 1934 & $14 \cdot 5$ \\
1927 & $19 \cdot 2$ & &
\end{tabular}

amount of variation from year to year, but it is not more than would be expected under the circumstances. The broad fact remains that tuberculosis in its various forms accounts for between one-sixth and one-seventh of all deaths in the Chinese of the urban areas of Hong Kong. It is second in order of frequency after bronchopneumonia. In England and Wales (MacNalty, 1932, p. 4) during the 4-year period 1926-9 the proportion was $8.5 \%$ for males, and $\mathbf{7 \cdot 1} \%$ for females, and the disease came fourth after cancer, myocardial degeneration and pneumonia (all forms) (Stat. Rev. 1931, Table VI).

It is necessary to allow for the fact that conditions for diagnosis in Hong Kong differ considerably from those in Great Britain. Tuberculosis in its later stages, when it is most commonly seen by the practitioner in the East, is an easily diagnosable condition, whereas many other diseases are not nearly so easily recognized without tests more elaborate than the average practitioner can undertake. In addition to this is the fact that when in doubt the doctor will tend to diagnose the more common rather than the rarer condition in his patient, if only because it is more often in his mind.

Table V shows the death rates at ages for tuberculosis for each of the census years. These data for males and females are shown in Graph 1.

Analysing the graph and table for 1921 the female rate is seen to be higher than the male until the middle of the fourth decade of life, except that at 10-14 they are equal. From 35 to 44 the rates run parallel with only a slight difference between them. The female adult maximum is at $45-54$, whereas the male is a decade later. The female curve has a fall after 45-54, and then a further rise at $65-74$, when it again nearly meets the male rate, after which they both fall in old age. In infancy the female rate is at the very high level of nearly 17,000 per million, and the male rate is only $20 \%$ less.

In the graph and table for 1931 the infant rate, though very high, is less than it was 10 years before. The female rate exceeds the male for the first 5 years of life, then for 5 years the curves cross and recross each other, but from ages 10 to 24 the female is the higher, after which the male rate remains the higher 
Table V. Tuberculosis, all forms, deaths at ages per 1000 living

\begin{tabular}{cccc} 
& \multicolumn{3}{c}{1921} \\
Age & Males & Females & Persons \\
$0-$ & $19 \cdot 77$ & $19 \cdot 66$ & $19 \cdot 72$ \\
$1-$ & $15 \cdot 05$ & $20 \cdot 07$ & $17 \cdot 55$ \\
$2-$ & $11 \cdot 15$ & $12 \cdot 77$ & $11 \cdot 96$ \\
$3-$ & $9 \cdot 96$ & $21 \cdot 92$ & $15 \cdot 36$ \\
$4-$ & $8 \cdot 33$ & $8 \cdot 54$ & $8 \cdot 44$ \\
$0-4$ & $13 \cdot 56$ & $16 \cdot 88$ & $15 \cdot 19$ \\
$5-$ & $7 \cdot 43$ & $9 \cdot 88$ & $8 \cdot 75$ \\
$6-$ & $3 \cdot 53$ & $6 \cdot 68$ & $5 \cdot 18$ \\
$7-$ & $2 \cdot 79$ & $2 \cdot 83$ & $2 \cdot 81$ \\
$8-$ & $2 \cdot 02$ & $2 \cdot 31$ & $2 \cdot 18$ \\
$9-$ & $0 \cdot 35$ & $1 \cdot 96$ & $1 \cdot 25$ \\
$5-9$ & $3 \cdot 18$ & $4 \cdot 65$ & $3 \cdot 97$ \\
$10-$ & $0 \cdot 85$ & $0 \cdot 82$ & $0 \cdot 84$ \\
$15-$ & $0 \cdot 83$ & $1 \cdot 62$ & $1 \cdot 06$ \\
$20-$ & $1 \cdot 30$ & $2 \cdot 03$ & $1 \cdot 51$ \\
$25-$ & $2 \cdot 46$ & $3 \cdot 73$ & $2 \cdot 87$ \\
$35-$ & $4 \cdot 10$ & $3 \cdot 69$ & $3 \cdot 96$ \\
$45-$ & $4 \cdot 30$ & $4 \cdot 11$ & $4 \cdot 23$ \\
$55-$ & $6 \cdot 45$ & $2 \cdot 57$ & $4 \cdot 80$ \\
$65-$ & $3 \cdot 74$ & $3 \cdot 45$ & $3 \cdot 63$ \\
$75-$ & $3 \cdot 13$ & $1 \cdot 78$ & $2 \cdot 27$
\end{tabular}

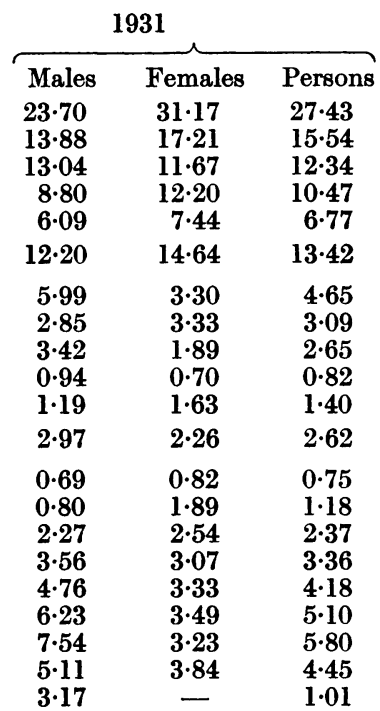

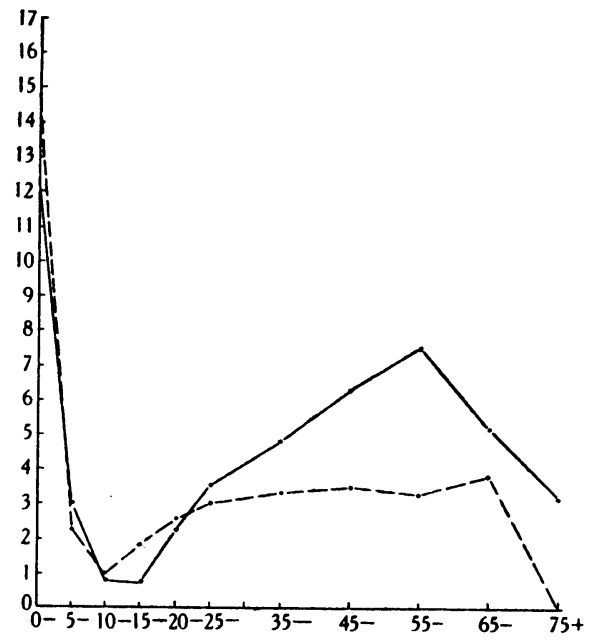

1921. Mortality in 1000's per million living at ages

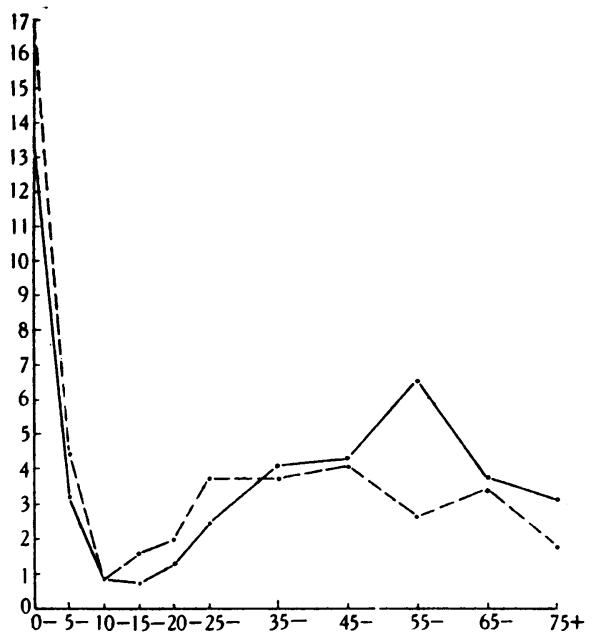

1931. Mortality in 1000's per million living at ages

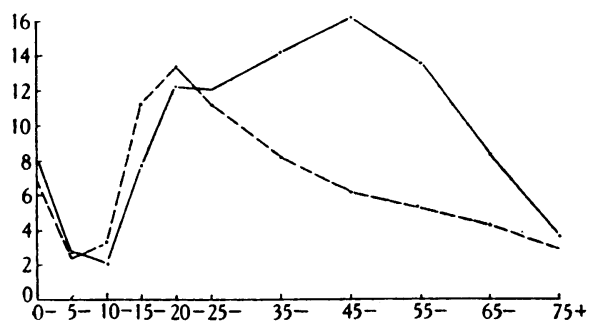

Mortality in 100's per million living at ages

Total tuberculosis England and Wales 1931. N.B. This Graph is to a vertical scale of 5 times that for the Graphs for Hong Kong

Graph 1. Total tuberculosis. Hong Kong and Kowloon. Males, ... Females 
for the rest of life. An interesting feature of the female curve is its plateau nature from early adult life until after 65 . In this respect it differs considerably from the English female curve, where the maximum incidence is at 20-24 years of age, and the level thereafter drops steadily to old age. The male curve, on the other hand, approximates more to the British type for males, except that the maximum incidence is a decade later in Hong Kong. In both the curves of 1921 and 1931 there are indications of a slight hump in early adult life, which is found in the corresponding British curve. One further feature of the Hong Kong curves is that the female mortality at 10-19 is about $50 \%$ higher than the corresponding male one, which is similar to what prevails in England and Wales.

The very heavy mortality from tuberculosis in infancy and early childhood is shown in another way in Table VI. This mortality is all the more significant when it is remembered that in 1921 children under 5 years of age constituted $7.71 \%$ of the population and in $19318.59 \%$, whereas in the standard British population of 1901 they formed $11.43 \%$.

Table VI. Deaths from tuberculosis at each age, expressed as a percentage of deaths from tuberculosis at all ages

\begin{tabular}{|c|c|c|c|c|c|c|}
\hline \multirow[b]{2}{*}{ Age } & \multicolumn{3}{|c|}{1921} & \multicolumn{3}{|c|}{1931} \\
\hline & Males & Females & Persons & Males & Females & Persons \\
\hline $0-$ & $25 \cdot 5$ & $39 \cdot 8$ & 31.9 & $22 \cdot 6$ & 38.8 & $29 \cdot 3$ \\
\hline $5-$ & $5 \cdot 0$ & $10 \cdot 8$ & $7 \cdot 5$ & $4 \cdot 8$ & $5 \cdot 2$ & 4.9 \\
\hline $10-$ & 1.9 & $2 \cdot 1$ & $2 \cdot 0$ & 1.2 & $2 \cdot 0$ & 1.6 \\
\hline $15-$ & $3 \cdot 5$ & $3 \cdot 6$ & 3.5 & $2 \cdot 8$ & $5 \cdot 0$ & $3 \cdot 7$ \\
\hline 20 & $5 \cdot 7$ & 4.7 & $5 \cdot 3$ & $8 \cdot 0$ & $7 \cdot 0$ & $7 \cdot 6$ \\
\hline 25- & $18 \cdot 0$ & $17 \cdot 1$ & $17 \cdot 6$ & $19 \cdot 4$ & $16 \cdot 3$ & $18 \cdot 1$ \\
\hline $35-$ & $21 \cdot 1$ & 11.9 & $17 \cdot 1$ & 17.9 & $12 \cdot 4$ & $15 \cdot 6$ \\
\hline $45-$ & $11 \cdot 2$ & $6 \cdot 8$ & 8.7 & $14 \cdot 0$ & 7.9 & 11.5 \\
\hline $55-$ & $6 \cdot 2$ & $2 \cdot 1$ & $4 \cdot 4$ & $7 \cdot 7$ & $3 \cdot 9$ & $6 \cdot 2$ \\
\hline $65-$ & 1.4 & 1.0 & 1.2 & $1 \cdot 4$ & 1.6 & 1.5 \\
\hline 75- & $0 \cdot 1$ & $0 \cdot 1$ & 0.1 & $0 \cdot 1$ & - & 0.07 \\
\hline Total deaths & 926 & 721 & 1647 & 1510 & 1057 & 2567 \\
\hline
\end{tabular}

Seasonal incidence of tuberculosis

All the deaths occurring during the period under review have been grouped according to the month in which they took place. The result is shown in Table VII. $54 \cdot 3 \%$ of deaths occur during the middle 6 months of the year,

Table VII. Deaths from all forms of tuberculosis, monthly and quarterly mortality, 1920-34

\begin{tabular}{|c|c|c|c|c|c|}
\hline Month & $\begin{array}{c}\text { Monthly } \\
\% \text { of } \\
\text { total }\end{array}$ & $\begin{array}{c}\text { Quarterly } \\
\% \text { of } \\
\text { total }\end{array}$ & Month & $\begin{array}{c}\text { Monthly } \\
\% \text { of } \\
\text { total }\end{array}$ & $\begin{array}{c}\text { Quarterly } \\
\% \text { of } \\
\text { total }\end{array}$ \\
\hline $\begin{array}{l}\text { January } \\
\text { February } \\
\text { March }\end{array}$ & $\begin{array}{l}7 \cdot 38 \\
7 \cdot 30 \\
8 \cdot 18\end{array}$ & & $\begin{array}{l}\text { July } \\
\text { August } \\
\text { September }\end{array}$ & $\begin{array}{l}9 \cdot 67 \\
8 \cdot 78 \\
8 \cdot 27\end{array}$ & \\
\hline 1st quarter & & $22 \cdot 86$ & 3rd quarter & & $26 \cdot 72$ \\
\hline $\begin{array}{l}\text { April } \\
\text { May } \\
\text { June }\end{array}$ & $\begin{array}{l}8 \cdot 84 \\
8 \cdot 73 \\
9 \cdot 96\end{array}$ & & $\begin{array}{l}\text { October } \\
\text { November } \\
\text { December }\end{array}$ & $\begin{array}{l}8 \cdot 45 \\
7 \cdot 49 \\
6 \cdot 94\end{array}$ & \\
\hline 2nd quarter & & $27 \cdot 54$ & 4th quarter & & $22 \cdot 88$ \\
\hline
\end{tabular}

Total number of tuberculosis deaths $\quad \ldots \quad 34,782$ 
and $45 \cdot 7 \%$ during the cold season. There is an opinion current among general practitioners in this part of the Far East that more tuberculosis is seen during the spring and summer than at other times of the year, but it has never had any statistical basis. The figures in Table VII show that there is little if any foundation in fact for this assumption.

\section{Tuberculosis, all forms, in China}

Owing to the paucity of statistics dealing with the incidence of the disease in China, there is no information about the epidemiology of tuberculosis among the Chinese. Almost all existing statistics relate to hospitals, which owing to the selection of cases which naturally takes place in any hospital, are bound to be fallacious. It must be remembered that there are no national means of ascertaining what diseases are prevalent in the population, nor their distribution or incidence. The National Health Organization (L.N.U. Ann. Epid. Rep. 1936) has during the last 3 years circulated certain hospitals and doctors requesting information on the prevalent infectious diseases in their districts, but such information is of little statistical value, although it is the only knowledge available.

For many years hospitals in China have issued annual reports about cases treated in their wards and out-patient departments. The information so given is scanty, and does not report on the incidence of different diseases.

It was not until 1933 that Gear $(1935 b)$ made a serious attempt to collect data from hospitals, and so to co-ordinate the information that conclusions could be drawn as to the distribution of the different forms of disease throughout the main hospitals of China. This survey was a review of all in- and outpatients treated in certain hospitals scattered widely up and down the country. Up to the present the results of 2 years are available. During 1933, out of 208,045 patients in seventeen hospitals, $4.9 \%$ were suffering from tuberculosis in one form or another, and the disease was fifth in order of frequency. In the survey for the next year, 1934, Gear (1936) gave the corresponding figures for twenty-five hospitals; of 266,509 patients, $4 \cdot 77 \%$ had tuberculosis, which was seventh in order of frequency.

Oldt (1933) made an analysis of the in- and out-patients of certain Canton hospitals, and found that of 31,122 cases, $6.5 \%$ were tuberculous. Concerning the incidence of tuberculosis in other large hospitals, Bume (1933) quotes Norman White as having stated that in $192365 \%$ of all admissions to the Shanghai gaol, the largest in the world, showed signs of tuberculosis, but I do not know what criteria he used. Anderson (1934), as a result of some careful work in this same prison and elsewhere in Shanghai, considered that the incidence of the disease in that city was in the neighbourhood of 6 per 1000 . 


\section{Tuberculin tests}

Though tuberculin tests do not show what is the morbidity rate of the disease in a population, they give an indication of the extent to which the people have been exposed to the infection at some time or other. The first tuberculin test to be carried out in China, so far as I am aware, was done by Korns (1925) in Peking on 2049 apparently healthy Chinese children aged from 8 to 20 years, who lived in Peking or Pao Ting Fu, North China. He used the von Pirquet test, employing $0 \cdot 1$ c.c. of a 1 in 100 dilution of O.T. and found that $30 \%$ of those examined gave a positive reaction, but he said that if the test were repeated there would probably be a higher percentage reacting. Anderson (1934) carried out a Mantoux test on some students of West China University, aged from 16 to 20 . He used $0.1 \mathrm{mg}$. of 1 in 1000 O.T. and obtained results sharply in contrast with Korns'. $87 \%$ were positive, with little difference between the different groups. This result was three times the percentage of that of the Peking group, and was almost certainly due to the greater sensitivity of the Mantoux test. Lai et al. (1934), using the same technique as Anderson, investigated a series of rural and a series of urban children and young people from Shanghai, there being 4703 in the combined series. They obtained an average value of $65 \%$ in the urban and $44.5 \%$ in the rural groups, with no sex differentiation. Wylie (1935) carried out a Mantoux test with similar technique on 600 children of the more prosperous classes of the rural community at Pao Ting Fu, North China. Their ages varied from 13 to 21; there was no significant difference between the sex rates, and the average for all was $85.5 \%$ positive, thus agreeing closely with Anderson in West China.

By way of contrast with the above, two tests carried out by de Haas (1933) on Chinese children living in Batavia, Java, are of interest. Using the von Pirquet technique, he found $40-45 \%$ of 596 poorer class children positive. De Haas et al. (1933), also in Java, and working with a similar group of 2394 Chinese children, found $40 \%$ positive under 6 years of age, $70 \%$ at $6-9$ years, and $80 \%$ at $10-14$ years of age. I have not found out what technique they employed.

For the Chinese in Hong Kong, only one survey has yet been published. Davis \& Guzdar (1935), using the Mantoux method according to D'Arcy Hart's technique, examined 259 urban Chinese, of whom 215 were adults. These gave a positive result in $93.1 \%$ of cases in dilutions of 1 in 1000 or higher. The series was not large enough to provide data concerning the frequency according to age groups.

\section{$X$-ray evidence}

Very little work has been published yet on the X-ray evidence of tuberculous changes in the lungs of Chinese. Hall \& Chang (1934) have reported on the results of the routine examination over a certain period by X-rays of all persons joining the staff, and of all graduates and undergraduates of the Peking Union 
Medical College. This series consisted of 1007 Chinese with a few Koreans and Eurasians, none of whom had been out of the country. They excluded all who showed signs prior to being $\mathrm{X}$-rayed, and they considered that their series represented as far as was possible the healthy young adult Chinese population. In no case was any symptom noticed by the person examined. They found that $81 \cdot 1 \%$ had evidence of old or recent trouble in the lungs, while $6.3 \%$ were suffering from manifest tuberculosis. Wylie (1935) found that of the 488 positive reactors in his series $8.2 \%$ showed pathological changes in the chest, as shown by fluoroscopy. His series, as already stated, consisted of the better classes living in the country, but there does not appear to be any great difference between the numbers showing pathological changes in his series and the results of Hall \& Chang's series.

Anderson (1935), in a series of 289 Chinese students at the Red Cross Hospital, Shanghai, found that $13 \cdot 3 \%$ of 135 males, and $7 \cdot 8 \%$ of 154 females showed radiographic evidence of intrathoracic scars. His interpretation of the difference in the sex incidence is that though the latent focus was present in equal number in the two sexes, the males were subjected to greater stresses throughout their lives, thus rendering themselves liable to extension of the disease from its childhood focus. No such work has been carried out in Hong Kong.

\section{Age and sex distribution}

In Gear's (1935b) survey, there were two males to every female, and in Oldt's (1933) Canton series there were four male patients to every three females suffering from tuberculosis. There were relatively very few children or old people in either series. To judge from hospital statistics, it would be assumed that tuberculosis is a disease of adult life, with little of it at the extremes, whereas the mortality figures show that it is a disease whose death-rate is relatively heaviest in infancy. The mortality throughout adult life is much more evenly distributed than would be assumed from a study of hospital data.

As regards the seasonal incidence of the disease, there is no reference in the literature as to what this may be in China.

\section{Overseas Chinese}

There appears to be singularly little literature dealing with deaths among overseas Chinese from tuberculosis. In the State of California (1936) it appears that 20 years ago there was a mortality as high as in Hong Kong, but that owing to causes about which I know nothing the rate is now less than half of what it then was, viz.

$$
\begin{array}{lllll}
1916 & \ldots & \ldots & 4670 \text { per million } \\
1921 & \ldots & \ldots & 4610 & , \\
1926 & \ldots & \ldots & 3630 & " \\
1931 & \ldots & \ldots & 2860 & " \\
1935 & \ldots & \ldots & 2280 & "
\end{array}
$$

Van Driel (1934), in an analysis of the causes of death and of invalidism of 31,300 Chinese estate labourers in the Dutch East Indies during the years 1931 and 1932, all aged between 19 and 55 , states that the mortality was 670 per million in the former year and 600 per million in the latter. These are not standardized rates. Postmus (1937) informs me that in a Chinese urban community at Medan, Sumatra, averaging 17,000, the crude death-rate for 1931-6 was 6.94 per 1000 , but there were also 1.23 deaths per 1000 that were of undetermined origin. 


\section{Pulmonary tUBerculosis}

This section will be concerned with $(a)$ the mortality from pulmonary tuberculosis in Hong Kong; $(b)$ with a review of the literature dealing with the same subject in China; $(c)$ a comparison of the data in $(a)$ and $(b)$.

\section{Pulmonary tuberculosis in Hong Kong}

The only data hitherto available as to the mortality from pulmonary tuberculosis in Hong Kong are those furnished by the medical department yearly, wherein the number of deaths from the disease and the crude deathrate per 1000 is given. Wellington (1934 and prior years) gives the information which I have summarized in Table VIII.

Table VIII. Annual mortality from pulmonary tuberculosis

$\begin{array}{cccc}\text { Year } & \begin{array}{c}\text { No. of deaths } \\ \text { from pulmonary } \\ \text { tuberculosis }\end{array} & \begin{array}{c}\% \text { of deaths } \\ \text { from all } \\ \text { causes }\end{array} & \begin{array}{c}\text { Deaths per } \\ \text { 1000 living } \\ \text { (crude rate) }\end{array} \\ 1934 & 2179 & 11 \cdot 0 & 2 \cdot 71 \\ 1933 & 2225 & 12 \cdot 3 & 2 \cdot 31 \\ 1932 & 2042 & 10 \cdot 3 & 2 \cdot 52 \\ 1931 & 1983 & 10 \cdot 6 & 2 \cdot 60 \\ 1930 & 1994 & 12 \cdot 3 & 1 \cdot 85 \\ 1929 & 2158 & 12 \cdot 3 & 2 \cdot 06 \\ 1928 & 1731 & 11.8 & 1 \cdot 78\end{array}$

Previous to 1928 there were no statistics published. The above figures refer to the total population of the Colony, and include Chinese, Europeans, Eurasians and non-Chinese Asiatics, and include deaths among the rural, urban and harbour populations. Pulmonary tuberculosis was the second commonest cause of death, coming after bronchopneumonia, except in 1928, when it was first in frequency, and in 1933, when it was third.

Table IX gives the standardized death rates for pulmonary tuberculosis calculated in the same manner as for all forms of tuberculosis (see p. 155). English figures are given for comparison.

Table IX. Pulmonary tuberculosis amongst urban Chinese. Standardized death-rates per million living

\begin{tabular}{cccccccc} 
& \multicolumn{3}{c}{ Hong Kong } & & \multicolumn{3}{c}{ England and Wales } \\
Year & $\overbrace{\text { Persons }}$ & Males & Females & & $\overbrace{\text { Persons }}$ & Males & Females \\
1921 & 2673 & 2510 & 2850 & 845 & 944 & 757 \\
1931 & 2731 & 3098 & 2422 & 686 & 780 & 601
\end{tabular}

It will be noted that both at 1931 and 1921 the rates for Hong Kong are 3-4 $\frac{1}{2}$ times as high as those for England and Wales, and that there appears no tendency towards improvement as in England.

Table X shows the mortality at ages, with English figures for comparison. The numbers dealt with in this table are not large, so that in making the following comparisons that fact must be borne in mind, and due allowance 
Table X. Pulmonary tuberculosis. Deaths at ages per million living

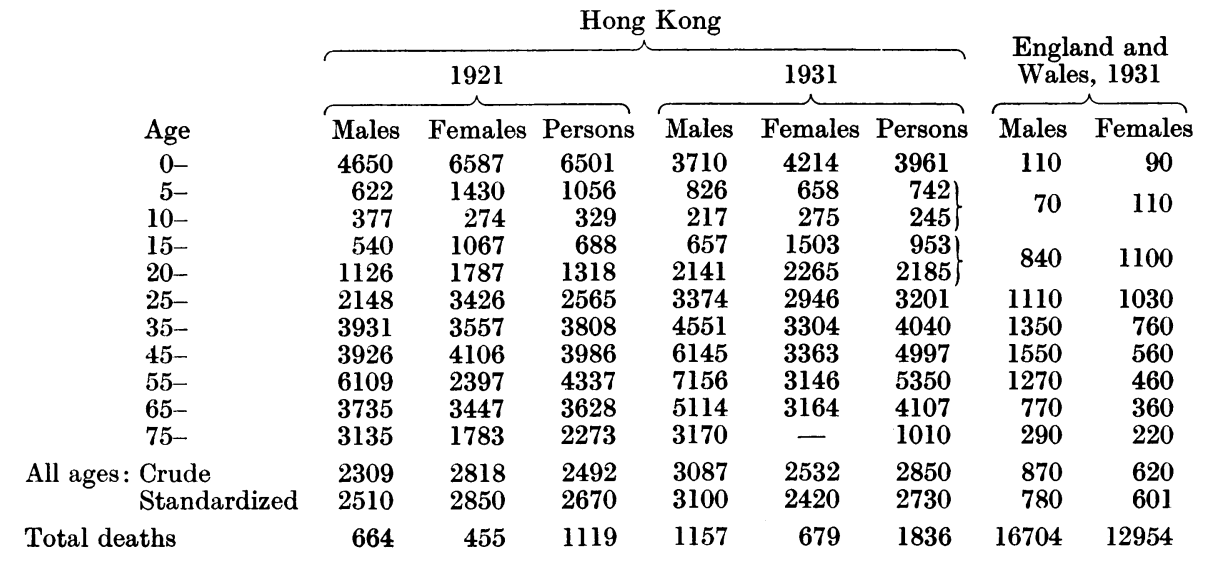

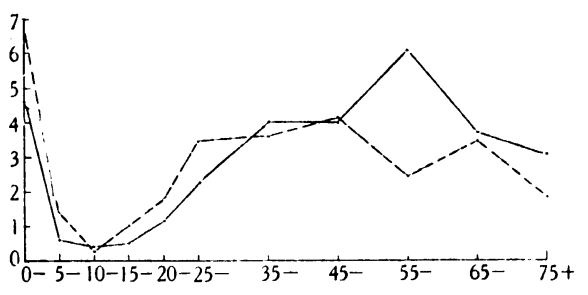

1921. Mortality in 1000's per million living at ages

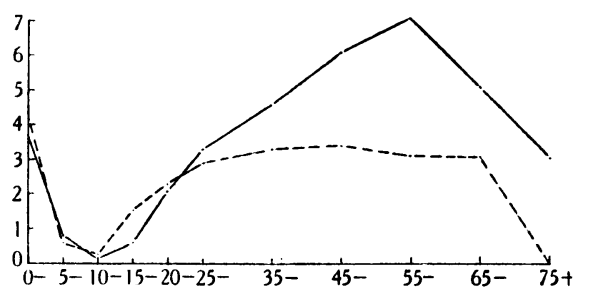

1931. Mortality in 1000 's per million living at ages

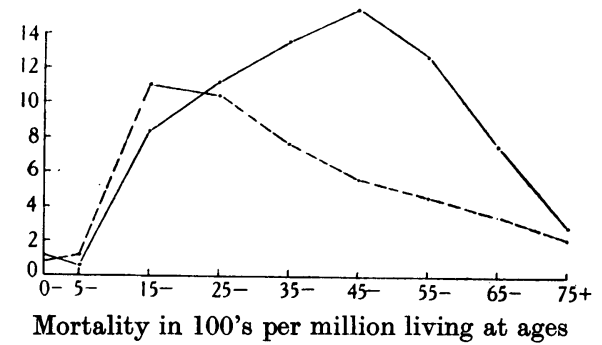

Pulmonary tuberculosis. England and Wales. 1931. N.B. The vertical scale of this chart is 5 times that of the ones above.

Graph II. Pulmonary tuberculosis. Death-rates per million living at ages, 1921 and 1931. — Males, .... Females.

must be made for it. There has been a rise between 1921 and 1931 of nearly 600 per million in the standardized death-rate for males, with a fall of about .400 per million in the female rate. The rate for persons has hardly changed. There has been a marked fall in infancy and childhood, more especially in females. By puberty this process has been reversed, and thereafter throughout life in males, but only in the fourth and fifth quinquennia and in the decade 55-64 in females was the rate in 1931 higher than in 1921. Apart from child- 
hood and old age, the persons rate was uniformly higher in the later than in the earlier year. The age of lowest incidence in Chinese is about the third quinquennium in both sexes, thus agreeing with what happens in England and Wales. In 1921 the rise in female mortality from puberty to the period 25-34 is more rapid than in males. This is not so marked in 1931. In both years the female adult curve is of the plateau type, except that in 1921 in the 35-44 group there is a drop, thus differing considerably from the English female curve where the maximum incidence is at $15-24$. The explanation in my opinion is to be found in the fact that in Hong Kong there is a continual stream of new arrivals in the Colony, young and middle-aged females coming to join their husbands after the latter have found work. In addition to this, they are to some extent protected from the cumulative strains of life to which their husbands are exposed while earning their living, so that the female mortality curve does not show the continual rise seen in the male curve.

In males the maximum incidence is 55-64, 10 years later than in England. From the age of 25 years onwards the male mortality in Hong Kong is above that of females, except in 1921 at 25-34 and at 45-54 years. The effects of the struggle for existence and the wear and tear of life show themselves very well in Graph 2, for becoming cumulative, they lead to the very high maximum incidence at 55-64 of 6100 per million living in 1921 and of 7100 in 1931.

In England and Wales during the fifties of last century the mortality from pulmonary tuberculosis was almost exactly the same as that of Hong Kong during the two census years under review, but the maximum male adult incidence was at ages $20-24$, being 4050 per million living, and in females, at $25-34$ with a rate of 4580 , these maxima being 25-35 years earlier than in Hong Kong. In comparing subsequent decades in England and Wales, with local rates, the most striking feature of the English incidence is its marked fall with the passage of time. There is not the slightest suggestion that such a fall has commenced yet in the Chinese urban population; if anything the incidence is rising.

A comparison is given below of the relative mortality from pulmonary tuberculosis and from tuberculosis, all forms, in Hong Kong and in England and Wales, with their respective percentages and standard deviations:

\begin{tabular}{|c|c|c|c|c|c|c|}
\hline Year & Place & $\begin{array}{c}\text { Tubercu- } \\
\text { losis } \\
\text { deaths }\end{array}$ & $\begin{array}{c}\text { Pulmonary } \\
\text { tubercu- } \\
\text { losis } \\
\text { deaths }\end{array}$ & $\begin{array}{c}\% \text { of all } \\
\text { tubercu- } \\
\text { losis } \\
\text { deaths }\end{array}$ & $\begin{array}{l}\text { S.D. of } \\
\%\end{array}$ & $\begin{array}{l}\text { S.D. of } \\
\text { difference }\end{array}$ \\
\hline 1921 & Hong Kong & 1647 & 1119 & 67.94 & $1 \cdot 15$ & \\
\hline 1921 & England and Wales & 42680 & 33505 & $78 \cdot 50$ & $0 \cdot 20$ & $1 \cdot 17$ \\
\hline 1931 & Hong Kong & 2657 & 1836 & $69 \cdot 10$ & $0 \cdot 89$ & \\
\hline 1931 & England and Wales & 35818 & 29658 & $82 \cdot 80$ & $0 \cdot 20$ & 0.91 \\
\hline
\end{tabular}

This lower incidence of pulmonary relative to tuberculosis, all forms, in Hong Kong is entirely due to the greater amount of the acute forms of the disease, such as miliary tuberculosis and tuberculous meningitis met with in the Colony. 
Expressed in 5-year periods, pulmonary tuberculosis in Hong Kong formed the following percentages of deaths from all causes:

$$
\begin{array}{rllllr}
1920-4 & \ldots & \ldots & \ldots & \ldots & 9 \cdot 7 \% \\
1925-9 & \ldots & \ldots & \ldots & \ldots & 13 \cdot 1 \% \\
1930-4 & \ldots & \ldots & \ldots & \ldots & 11 \cdot 2 \%
\end{array}
$$

In England and Wales the corresponding percentages for the year 1929 were $7 \cdot 9 \%$ for males and $6.4 \%$ for females.

\section{Seasonal incidence}

The seasonal incidence of pulmonary tuberculosis for the years 1920-34 is given in Table XI. As in the other forms of tuberculosis, there is a slight preponderance of deaths in the middle 6 months of the year.

Table XI. Pulmonary tuberculosis. Seasonal incidence, 1920-34

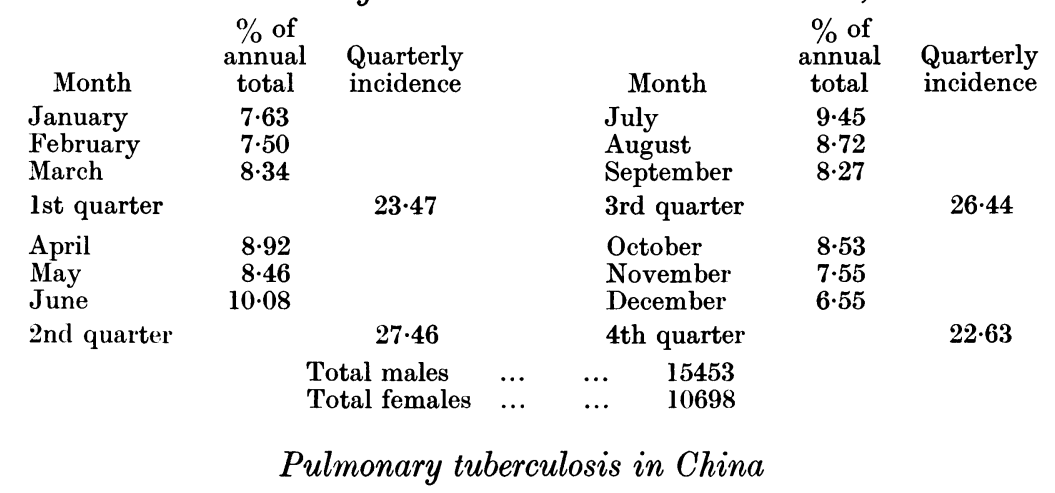

As in the case of tuberculosis, all forms, the only data of any interest regarding the incidence of pulmonary tuberculosis in China deal with the cases seen in certain hospitals. By far the most important up to the present is Gear's (1935b) survey, already referred to. His results may be summarized thus:

(a) Of 190,475 in- and out-patients seen in sixteen hospitals throughout China in 1933, 5992 or $3.1 \%$ were suffering from lung tuberculosis.

(b) The geographical distribution of this form was as follows:

In North China it formed $48 \%$ of 1472 tuberculosis cases

$\begin{array}{llll}\text { In Central China } & , & 71 \% \text { of } 6378 & , \\ \text { In South China } & " & 59 \% \text { of } 1299 & " \\ \text { In all China } & , & 65 \% \text { of } 9149 & ,\end{array}$

(c) Concerning the age distribution, the largest group in both sexes was that for 15-34 years, the next largest being that for 25-34 years, also for both sexes. Females predominated only in the childhood groups.

Chun (1928) at Harbin in the north obtained a low pulmonary rate of $18.1 \%$ of 2962 tuberculosis cases, this being at variance with all other hospital statistics, so that there was probably some selection in the cases dealt with at his hospital. Korns, quoted by Gear (1935b), had a rate of $49 \cdot 8 \%$ in 3063 
tuberculosis cases. Oldt (1933) found two peaks of maximum incidence in his series of 1183 cases:

Males at 20-24, and later at 40-44 years.

Females at 25-29, and later at 40-44 years.

Anderson (1934) found that of all admissions during 1932 to the Shanghai prison hospital, $4 \cdot 1 \%$ were for pulmonary tuberculosis, of whom $54.7 \%$ died of the disease or its complications, and indeed $76.8 \%$ of all deaths in the prison were from pulmonary tuberculosis, half of whom died within $3 \frac{1}{2}$ months of admission to gaol. The average annual number of admissions to this prison is 13,000 .

All the above statistics refer to hospitals. I am not aware of any other figures concerning the incidence of the disease which are accurate. In the League of Nations Annual Epidemiological Report (1936), where returns from various parts of the world are published recording the annual death-rates from pulmonary tuberculosis, those for Canton are given as

$\begin{array}{lllllll}1931 & \ldots & \ldots & \ldots & \ldots & 849 \text { per million } \\ 1932 & \ldots & \ldots & \ldots & \ldots & 700 & \\ 1933 & \ldots & \ldots & \ldots & \ldots & 724 & ,\end{array}$

These figures, were they accurate, show a death-rate only slightly higher than that for England and Wales, and only a quarter of that for Hong Kong, a neighbouring city which has a much better sanitary and medical administration. I am not aware of any experienced doctor in Canton who would accept them, if only because there is no effective compulsory certification of death.

\section{Comparison of the data from Hong Kong and from China}

The proportion which pulmonary tuberculosis bears to that from all forms appears to be the same in Hong Kong as it is in the hospitals surveyed in Gear's report. The sex incidence of Chinese hospitals shows that two males are treated for every female. This is so for the majority of diseases, the reason probably being that women are considered of less importance than men, and their ailments are of less concern for the family. Other reasons are (1) that the housewife can ill be spared to go to hospital for treatment, and (2) the natural conservatism of Chinese women makes them prefer native to western medical treatment.

What was said above about the age distribution in Chinese hospitals for tuberculosis, all forms, applies here too, namely, that the extremes of life are not nearly so well represented in the hospital statistics as they would have been if the hospital morbidity rate bore any relation to the mortality rate.

\section{Miliary TUBerCULOSIS}

This section will investigate the mortality from generalized or miliary tuberculosis in Hong Kong. Table XII shows the standardized death-rate from this cause. I have been unable to find out in Hong Kong what are the 
Table XII. Miliary tuberculosis. Standardized death-rate per million living

$\begin{array}{cccc}\text { Year } & \text { Persons } & \text { Males } & \text { Females } \\ 1921 & 1059 & 951 & 1214 \\ 1931 & 760 & 653 & 893\end{array}$

standardized death-rates for this form of tuberculosis in England and Wales, but the crude death-rate in 1921 and 1931 was

\begin{tabular}{|c|c|c|c|c|c|c|c|}
\hline 1921 & Males & $\ldots$ & 62 per million & 1931 & Males & $\ldots$ & 37 per million \\
\hline & Females & $\ldots$ & 49 & & Females & $\ldots$ & 28 \\
\hline & Persons & $\ldots$ & 55 & & Persons & $\ldots$ & 32 \\
\hline
\end{tabular}

There has been a decline in the mortality from miliary tuberculosis in Hong Kong during the last 15 years, but even so the rate is from 16 to 19 times the English rate. This high rate is in keeping with experience which shows that the more acute forms of tuberculosis are much more frequently met with in Hong Kong than in England.

The mortality at ages is shown in Table XIII. This table shows the extremely high mortality in the first decade of life, after which it falls rapidly.

Table XIII. Miliary tuberculosis. Mortality at ages per million living. Hong Kong, 1931

$\begin{array}{rccc}\text { Age } & \text { Persons } & \text { Males } & \text { Females } \\ 0- & 5480 & 4390 & 6570 \\ 5- & 820 & 910 & 740 \\ 10- & 230 & 150 & 310 \\ 15- & 90 & 20 & 210 \\ 20- & 60 & 50 & 70 \\ 25- & 40 & 50 & 20 \\ 35- & 20 & 40 & - \\ 45- & 50 & 90 & - \\ 55- & 110 & 190 & - \\ 65- & - & - & - \\ 75- & - & - & -\end{array}$

Seasonal incidence of miliary tuberculosis

There is a definite though small seasonal incidence in the mortality from this disease:

$$
\begin{array}{ccccc}
\text { Jan.-Mar. } & \ldots & \ldots & 1082 \text { or } 20 \cdot 99 \% \text { of all miliary tuberculosis } \\
\text { Apr.-June } & \ldots & \ldots & 1432 \text { or } 27 \cdot 77 & , \\
\text { July-Sept. } & \ldots & \ldots & 1422 \text { or } 27 \cdot 58 & , \\
\text { Oct.-Dec. } & \ldots & \ldots & 1219 \text { or } 23 \cdot 65 & , \\
\text { Total } & \ldots & \ldots & 5155
\end{array}
$$

Approximately $55 \%$ of the deaths occur in the middle 6 months of the year. 


\section{Age incidence of miliary tuberculosis}

Table XIV shows the age incidence of deaths from miliary tuberculosis during the 15 years covered by this survey. Over four-fifths of all deaths have

Table XIV. Miliary tuberculosis. Percentage age distribution of deaths, 1920-34

$\begin{array}{ccc}\text { Age } & \text { Males } & \text { Females } \\ 0- & 67 \cdot 1 & 71 \cdot 8 \\ 5- & 14 \cdot 4 & 16 \cdot 2 \\ 10- & 4 \cdot 4 & 5 \cdot 7 \\ 15- & 2 \cdot 0 & 2 \cdot 0 \\ 20- & 1 \cdot 9 & 0 \cdot 8 \\ 25- & 3 \cdot 7 & 2 \cdot 0 \\ 35- & 2 \cdot 8 & 0 \cdot 8 \\ 45- & 2 \cdot 5 & 0 \cdot 4 \\ 55- & 1 \cdot 0 & 0 \cdot 1 \\ 65- & 0 \cdot 2 & 0 \cdot 1 \\ 75- & - & 0 \cdot 1 \\ \text { Total no. of deaths } & 2509 & 2646\end{array}$

occurred before the tenth year of age. Relatively females predominate at ages under 20 , after that age there are proportionately three times as many male deaths as female deaths.

The ratio of miliary tuberculosis to tuberculosis, all forms, during the decade 1921-30 in Hong Kong and in England and Wales is shown below.

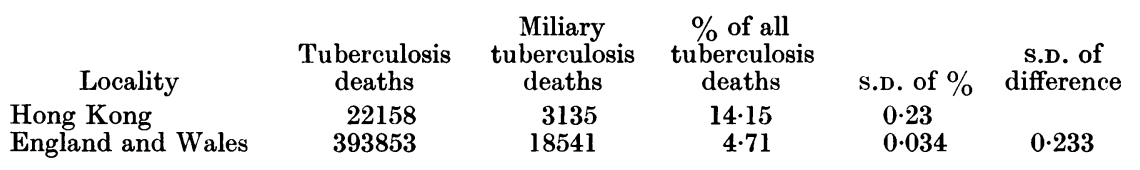

Concerning the incidence of this disease in China there is no information available, because hospitals do not appear to class it by itself.

\section{Abdominal tuberculosis}

This subject will be discussed in relation to $(a)$ its mortality in Hong Kong, and $(b)$ its incidence in China. By abdominal tuberculosis is meant tuberculosis of the intestines and peritoneum, number 25 in the International List of the Causes of Death.

Table XV shows the standardized death-rates for this disease in Hong Kong.

Table XV. Abdominal tuberculosis. Standardized death-rates, 1921 and 1931

$\begin{array}{cccc}\text { Year } & \text { Persons } & \text { Males } & \text { Females } \\ 1921 & 282 & 255 & 313 \\ 1931 & 113 & 114 & 111\end{array}$

Between 1921 and 1931 the rate dropped from 282 per million to 113 per million for persons. There has been no great alteration in the housing conditions nor in the structure of the population; there may have been a change in diag- 
nostic nomenclature about that time which caused the fall in the rate, but if so, I am unaware of it. I am not prepared to offer a satisfactory explanation of this drop.

The death-rate at ages is shown in Table XVI. The relative mortality from

\begin{tabular}{|c|c|c|c|c|c|}
\hline \multirow[b]{2}{*}{ Age } & \multicolumn{3}{|c|}{ Hong Kong } & \multicolumn{2}{|c|}{ England and Wales } \\
\hline & Males & Females & Persons & Males & Females \\
\hline 0 & 535 & 536 & 535 & 110 & 85 \\
\hline $5-$ & $\begin{array}{r}206 \\
36\end{array}$ & 82 & $\begin{array}{c}144 \\
56\end{array}$ & 29 & 23 \\
\hline $15-$ & $\begin{array}{l}30 \\
38\end{array}$ & $\begin{array}{l}78 \\
35\end{array}$ & $\begin{array}{l}56) \\
37 !\end{array}$ & & \\
\hline $20-$ & 38 & 69 & $49)^{3}$ & 29 & 35 \\
\hline 25- & 36 & 72 & 50 & 14 & 30 \\
\hline $35-$ & 53 & 25 & 42 & 16 & $\begin{array}{l}19 \\
16\end{array}$ \\
\hline $\begin{array}{l}45- \\
55-\end{array}$ & & & & $\begin{array}{l}15 \\
16\end{array}$ & $\begin{array}{l}16 \\
17\end{array}$ \\
\hline $\begin{array}{l}65- \\
75-\end{array}$ & 37 & 47 & 42 & $\begin{array}{l}9 \\
6\end{array}$ & $\begin{array}{r}15 \\
4\end{array}$ \\
\hline All ag & 114 & 111 & 112 & 31 & 32 \\
\hline
\end{tabular}

abdominal tuberculosis in Hong Kong and in England and Wales for the decade $1921-30$ is shown below:

$\begin{array}{lcccc}\text { Locality } & \begin{array}{c}\text { Tuberculosis, } \\ \text { all forms }\end{array} & \begin{array}{c}\text { Abdominal } \\ \text { tuberculosis }\end{array} & \begin{array}{c}\% \text { of all } \\ \text { tuberculosis }\end{array} & \begin{array}{c}\text { s.D. of \% } \\ \text { Hong Kong }\end{array} \\ 22158 & 731 & 3 \cdot 30 & 0 \cdot 12 \\ \text { England and Wales } & 393853 & 16133 & 4 \cdot 10 & 0 \cdot 032\end{array}$

Compared with other forms of tuberculosis it is not common, being rather less common than it is in Britain. It is, however, commoner than would be expected, because it is not due to the bovine tubercle bacillus. Cow's milk is not drunk by the Chinese, nor is meat other than pork eaten by them (Gear, $1935 b)$. The animals kept by the Chinese are pigs, water buffaloes and goats. Gear \& Petersen (1934) have shown that tuberculosis is rare among these animals in China. Minett (1930) states that tubercle bacilli have never been found in the milk of Hong Kong (the consumption of which is almost entirely limited to Europeans), and that he had never found the bovine form in the intestinal lesions of children at the Hong Kong public mortuary. Oldt (1933) similarly states that there is very little chance for Chinese children to become infected with bovine tubercle bacilli. The most authoritative article that has appeared up to the present on this subject is Scott's (1921), where he carefully analyses the pathological findings in a series of 300 post-mortem examinations in tuberculous Chinese. In no case did he find any evidence of a bovine infection. The mode of infection is obvious to anyone who will take the trouble to observe what happens in the overcrowded tenements of the city. Expectoration on the floor is universal, babies and small children in plenty crawl about the floor, they put their fingers in the sputa, and afterwards their fingers find their way to their mouths. In this way active tubercle bacilli are conveyed to the intestine, and a high infantile rate is the result. 


\section{Seasonal incidence}

The seasonal incidence of abdominal tuberculosis for the 15 years under review is shown in Table XVII. As with other forms of tuberculosis, the majority of the deaths occur in the middle 6 months of the year.

Table XVII. Abdominal tuberculosis. Seasonal incidence, 1920-34

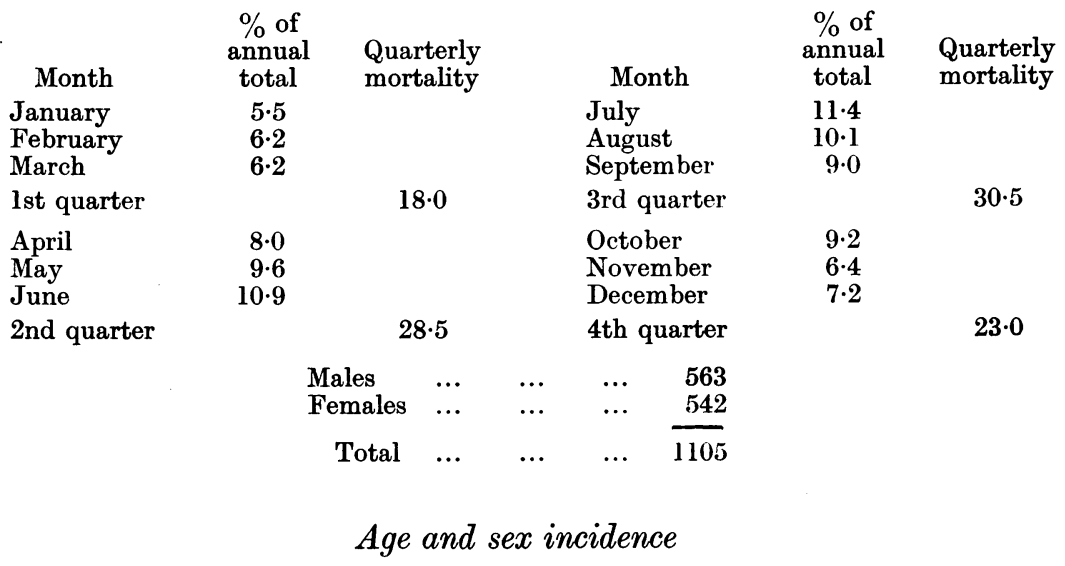

Table XVIII shows the distribution of the disease according to age. The distribution of mortality is about the same in the two sexes, chiefly because

Table XVIII. Abdominal tuberculosis. Age incidence, 1920-34

\begin{tabular}{ccc} 
& \multicolumn{2}{c}{$\%$ of all ages } \\
\cline { 2 - 3 } Age & Males & Females \\
$0-$ & $71 \cdot 5$ & $71 \cdot 3$ \\
$5-$ & $8 \cdot 3$ & $12 \cdot 9$ \\
$10-$ & $3 \cdot 1$ & $4 \cdot 0$ \\
$15-$ & $2 \cdot 8$ & $2 \cdot 2$ \\
$20-$ & $1 \cdot 8$ & $2 \cdot 9$ \\
$25-$ & $4 \cdot 9$ & $3 \cdot 5$ \\
$35-$ & $4 \cdot 6$ & $2 \cdot 4$ \\
$45-$ & $1 \cdot 6$ & $0 \cdot 7$ \\
$55-$ & $1 \cdot 3$ & $0 \cdot 2$ \\
$65-$ & - & $1 \cdot 5$
\end{tabular}

three-quarters of all deaths occur in childhood, when the numbers of the two sexes in the population are about equal, and there is no difference in the sex mortality at that age.

\section{Incidence of abdominal tuberculosis in China}

As with other forms of tuberculosis, there are no mortality figures available; one is dependent on hospital data for evidence as to the prevalence and age distribution of abdominal tuberculosis in China. 
Gear $(1935 b)$ in his survey found the following to be the incidence and regional distribution of this form in China:

$\begin{array}{ccccc}\text { Region } & \begin{array}{c}\text { Male } \\ \text { incidence }\end{array} & \begin{array}{c}\text { Female } \\ \text { incidence }\end{array} & \overbrace{\text { Males }}^{\text {tuberculosis seen }} \\ \text { North China } & 3 \cdot 97 & 4 \cdot 69 & 982 & \text { Females } \\ \text { Central China } & 2 \cdot 45 & 5 \cdot 10 & 4535 & 490 \\ \text { South China } & 3 \cdot 87 & 4.55 & 749 & 1843 \\ \text { Total area } & 2 \cdot 86 & 4.93 & 6266 & \mathbf{5 5 0}\end{array}$

The above is an incidence of $3.5 \%$ in a total of 9149 cases of all forms of tuberculosis.

Gear quotes Korns as stating that $4.83 \%$ of all tuberculosis in his Peking series of 3063 cases were due to this form. Similarly Chun (1928) found an incidence of $0.95 \%$ of 2962 tuberculosis cases in Harbin, $6.2 \%$ of 706 cases in Tsinan, and no case in a series of 413 in Shanghai. In Gear's series, the majority of the cases seen in the hospitals were in late childhood or in their teens or early adult life.

\section{TUBERCULOSIS OF THE NERVOUS SYSTEM}

This section will be concerned with the mortality from this form of tuberculosis in Hong Kong, and with what is known about its incidence in China.

The standardized death-rate for tuberculosis of the nervous system in Hong Kong for the census years 1921 and 1931 is shown in Table XIX. There

Table XIX. Tuberculosis of the nervous system. Standardized death-rates per million living, 1920-34

$\begin{array}{lcccccc}\text { Year } & \overbrace{\text { Persons }} & \text { Males } & \text { Females } & & \overbrace{\text { Males }}^{\text {England and Wales }} \\ 1921 & 262 & 268 & 256 & 113 & 110 \\ 1931 & 356 & 469 & 441 & 91 & 84\end{array}$

is a general tendency for the mortality to increase over the period under discussion in Hong Kong, while in Britain it is falling. In 1921 the rate was $2 \frac{1}{2}$ times, and in 1931 it was about 5 times as high as in England. The sex ratio was about the same in the two places.

The relative mortality for England and Wales and for Hong Kong for the years $1921-30$ is shown below:

Hong Kong

England and Wales

$$
\begin{array}{cccc}
\begin{array}{c}
\text { Tuberculosis } \\
\text { of the nervous } \\
\text { system }
\end{array} & \begin{array}{c}
\% \text { of all } \\
\text { cases of } \\
\text { tuberculosis }
\end{array} & \begin{array}{c}
\text { s.D. of } \% \\
1,071
\end{array} & \begin{array}{c}
\text { S.83 } \\
\text { difference }
\end{array} \\
29,383 & 7 \cdot 46 & 0 \cdot 144 & - \\
& 0.042 & 0 \cdot 15
\end{array}
$$

The death-rate per million living at ages is shown in Table XX.

In Hong Kong the mortality in adults is less than in England and Wales, but in infancy and childhood during the last 7 or 8 years it has become enormous, being of far more importance numerically than abdominal tuber- 
Table XX. Tuberculosis of the nervous system. Death-rate per million living, 1931

\begin{tabular}{|c|c|c|c|c|c|}
\hline \multirow[b]{2}{*}{ Age } & \multicolumn{3}{|c|}{ Hong Kong } & \multicolumn{2}{|c|}{ England and Wales } \\
\hline & Persons & Males & Females & Males & Females \\
\hline 0 & 3030 & 3070 & 3000 & 464 & 392 \\
\hline $5-$ & 800 & 910 & $700\}$ & 104 & 112 \\
\hline $10-$ & 90 & 140 & $40\}$ & 104 & 112 \\
\hline $15-$ & 40 & 一 & 100\{ & 5 & 55 \\
\hline 20 & 40 & 40 & $10\}$ & 52 & bo \\
\hline $25-$ & 10 & - & $40^{-}$ & 21 & 19 \\
\hline $35-$ & 10 & 20 & 一 & 13 & 8 \\
\hline $45-$ & - & $\ldots$ & - & 7 & 7 \\
\hline $55-$ & $\ldots$ & $\ldots$ & - & 5 & 3 \\
\hline 65- & - & 一 & - & 1 & 4 \\
\hline 75- & - & - & - & - & - \\
\hline All ages & 456 & 469 & 441 & 91 & 84 \\
\hline
\end{tabular}

culosis. A careful clinical and pathological investigation would be necessary before one could give adequate reasons for this, but considered epidemiologically, some of the causes are to be found in the intense overcrowding in the city, and the family habits of the Chinese in the tenements.

The age incidence of death is shown in Table XXI. About $90 \%$ of all the

Table XXI. Tuberculosis of the nervous system. Percentage age

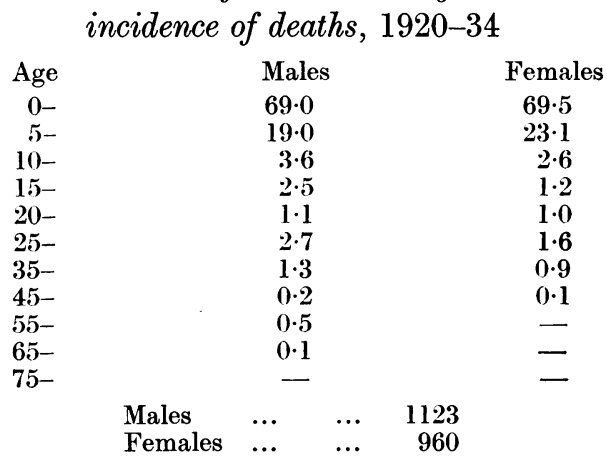

deaths occur before the end of the ninth year. The seasonal incidence is shown in Table XXII. There is a predominance of deaths in the middle 6 months of the year, as occurs in the other forms of tuberculosis in Hong Kong.

Table XXII. Tuberculosis of the nervous system. Seasonal incidence, 1920-34

\begin{tabular}{|c|c|c|c|c|c|}
\hline Month & $\begin{array}{c}\% \text { of the } \\
\text { year's } \\
\text { total }\end{array}$ & $\begin{array}{l}\text { Quarterly } \\
\text { incidence }\end{array}$ & Month & $\begin{array}{c}\% \text { of the } \\
\text { year's } \\
\text { total }\end{array}$ & $\begin{array}{l}\text { Quarterly } \\
\text { incidence }\end{array}$ \\
\hline $\begin{array}{l}\text { January } \\
\text { February } \\
\text { March }\end{array}$ & $\begin{array}{l}7 \cdot 5 \\
7 \cdot 0 \\
7 \cdot 8\end{array}$ & & $\begin{array}{l}\text { July } \\
\text { August } \\
\text { September }\end{array}$ & $\begin{array}{l}9 \cdot 9 \\
7 \cdot 8 \\
8 \cdot 6\end{array}$ & \\
\hline 1st quarter & & $22 \cdot 3$ & 3rd quarter & & $26 \cdot 3$ \\
\hline $\begin{array}{l}\text { April } \\
\text { May } \\
\text { June }\end{array}$ & $\begin{array}{l}8 \cdot 8 \\
9 \cdot 6 \\
9 \cdot 1\end{array}$ & & $\begin{array}{l}\text { October } \\
\text { November } \\
\text { December }\end{array}$ & $\begin{array}{l}7 \cdot 9 \\
6 \cdot 7 \\
9 \cdot 3\end{array}$ & \\
\hline 2nd quarter & & $27 \cdot 5$ & 4th quarter & & $23 \cdot 9$ \\
\hline
\end{tabular}




\section{Incidence in China}

Gear (loc. cit.) found that the following was the incidence and regional distribution of the disease in China:

\begin{tabular}{lcrcrcc}
\multicolumn{1}{c}{ Males } & \multicolumn{3}{c}{ Females } & Persons & \\
$\quad$ Area & $\%$ & Cases & $\%$ & Cases & $\%$ & Cases \\
North China & $1 \cdot 02$ & 982 & $0 \cdot 61$ & 490 & $0 \cdot 88$ & 1472 \\
Central China & $0 \cdot 44$ & 4535 & $0 \cdot 78$ & 1843 & $0 \cdot 56$ & 6378 \\
South China & $2 \cdot 27$ & 749 & $1 \cdot 71$ & 550 & $2 \cdot 00$ & 1299 \\
Total area & 0.75 & 6266 & 0.97 & 2883 & $0 \cdot 82$ & 9149
\end{tabular}

$\mathrm{Wu}$ (1936), in an investigation of 200 cases of bacteriologically proved tuberculous meningitis at the Peking Union Medical College, found that 111 were in males, and eighty-nine in females, and that the age incidence was

$$
\begin{aligned}
& 4.0 \% \text { under } 6 \text { months of age, } \\
& 8.5 \% \text { between } 6 \text { months and } 1 \text { year, } \\
& 26.5 \% \text { between } 2 \text { years and } 4 \text { years, } \\
& 18.5 \% \text { between } 5 \text { years and } 12 \text { years, } \\
& 42.5 \% \text { at } 13 \text { years and over. }
\end{aligned}
$$

$\mathrm{Wu}$ states that the disease, which is present all the year round, tends to be a spring and autumn condition, but his graph of the seasonal incidence shows less variation than does Table XXII, except for an autumn fall. It is evident from the age incidence of his series that either the disease is much rarer in children in the North than in Hong Kong, or, what is much more likely, the children are not taken to hospital.

\section{Remaining Forms OF TUBERCULOSIS}

\section{Bone and joint tuberculosis}

This form (including that of the vertebral column) is uncommon in the urban areas of Hong Kong. During the 15 years under review, only 193 deaths were certified as being due to it out of over 34,000 tuberculosis deaths, being an incidence of $0.55 \%$ over the whole period, an average of 13 a year. A comparison is made below between the mortality in Hong Kong of bone and joint tuberculosis during these 15 years, and that for England and Wales for the decade 1921-30:

$\begin{array}{lcccc}\text { Locality } & \begin{array}{c}\text { Total } \\ \text { tuberculosis }\end{array} & \begin{array}{c}\text { Bone and joint } \\ \text { tuberculosis }\end{array} & \begin{array}{c}\% \text { of total } \\ \text { tuberculosis }\end{array} & \begin{array}{c}\text { s.D. of \% } \\ \text { Hong Kong }\end{array} \\ \text { England and Wales } & \mathbf{3 4 , 7 8 2} & 193 & 0.55 & 0.0397 \\ & \mathbf{3 9 3 , 8 5 3} & \mathbf{9 , 0 0 9} & \mathbf{2 . 2 9} & \mathbf{0 . 0 2 3 8}\end{array}$

The standardized rate for 1921 was 0.022 , and in 1934 it was 0.035 per 1000 . The age incidence of deaths from this form of tuberculosis is given in Table XXIII. There was no significant difference in the mortality of the sexes. As compared with Britain, the age incidence of death is a much younger one. During the decade $1921-30$ in England $15.9 \%$ of all the mortality from this form of tuberculosis occurred under the age of 15 years. In Hong Kong during the 15 years under discussion the corresponding percentage was $58 \cdot 6$. 
Table XXIII. Percentage age incidence of deaths, 1920-34. Bone, joint and vertebral tuberculosis

$\begin{array}{rrrr}\text { Age } & \% & \text { Age } & \% \\ 0- & 7 \cdot 8 & 25- & 11 \cdot 4 \\ 5- & 31 \cdot 6 & 35- & 5 \cdot 2 \\ 10- & 19 \cdot 2 & 45- & 3 \cdot 6 \\ 15- & 12 \cdot 4 & 55- & 1 \cdot 0 \\ 20- & 7 \cdot 3 & 65- & 0 \cdot 5\end{array}$

Bone and joint tuberculosis in China

Gear (loc. cit.) states that the regional distribution in his series was

North China $\quad \ldots \quad \ldots \quad 26.99 \%$ of 1472 tuberculosis cases.

Central China ... ... $13.61 \%$ of $6378 \quad$,

South China $\quad \ldots \quad \ldots \quad 21.94 \%$ of $1299 \quad$,

All China $\quad \ldots \quad \ldots \quad 17 \cdot 11 \%$ of $9149 \quad$,

In Hong Kong the mortality from bone tuberculosis is $0.55 \%$ of all tuberculosis deaths; in Gear's series the incidence was $17 \%$ of all tuberculosis admissions to hospitals, so one must assume that an unduly large proportion of bone cases find their way to hospitals, because there is no evidence to suggest that bone tuberculosis is excessively common in relation to other forms in China as compared with Hong Kong.

\section{Gland tuberculosis}

In Hong Kong during the period under review there were only eighty deaths certified as being due to gland tuberculosis. This represents an incidence of $0.22 \%$ of all tuberculosis deaths. The age distribution is shown in Table XXIV. In England and Wales during the decade 1921-30 there were 957

Table XXIV. Gland tuberculosis. Age distribution, 1920-34

$\begin{array}{rccc}\text { Age } & \text { \% of whole } & \text { Age } & \% \text { of whole } \\ 0- & 31 \cdot 25 & 25- & 6 \cdot 25 \\ 5- & 22 \cdot 50 & 35- & 6 \cdot 25 \\ 10- & 11 \cdot 25 & 45- & 1.25 \\ 15- & 8 \cdot 75 & 55- & 1 \cdot 25 \\ 20- & 11 \cdot 25 & & \end{array}$

deaths from this form of tuberculosis, being $0 \cdot 242 \%$ of 393,853 tuberculosis deaths.

Gear (loc. cit.) states that $9 \cdot 61 \%$ of his series of 9149 tuberculosis cases were due to gland tuberculosis, and that it is commoner in North China (14.94\% of 1472 cases) than in Central China $(8.42 \%$ of 6378 cases) or South China (9.39\% of 1299 cases).

Other forms of tuberculosis in Hong Kong accounted for only fifteen deaths during the 15 years under discussion. They were all due to genito-urinary tuberculosis. In Gear's series these cases make up $2 \cdot 49 \%$ of his total. 


\section{The relative mortality from tuberculosis in Hong Kong AND Kowloon}

In the first section the conditions prevailing in the two cities of Victoria and Kowloon were discussed; it now remains to compare the mortality from tuberculosis in the two places. As already stated, the census figures are not complete enough to enable me to give separate standardized death-rates, nor to investigate the differences in the sex and age distribution of the populations in the two cities, but it is possible to give a comparison of the crude death-rates for the different forms of the disease.

By dividing the Victoria crude death-rate by the Kowloon crude death-rate, it is possible to show the relative mortality in the two cities (Table XXV).

Table XXV. Hong Kong and Kowloon. Relative mortality from tuberculosis. Average of the years 1920-34

$\begin{array}{ll}\text { Tuberculosis, all forms } & \mathbf{1} 43 \\ \text { Pulmonary tuberculosis } & \mathbf{1 \cdot 3 2} \\ \text { Miliary tuberculosis } & \mathbf{2 \cdot 4 3} \\ \text { Tuberculous meningitis } & \mathbf{2 \cdot 1 2} \\ \text { Abdominal tuberculosis } & \mathbf{1 \cdot 2 2} \\ \text { Other forms of tuberculosis } & \mathbf{1 \cdot 7 9}\end{array}$

If the deaths in the two cities are investigated, the percentages of all forms dying in each city are seen in Table XXVI. The density of population per acre

Table XXVI. Hong Kong and Kowloon. Percentage of deaths from tuberculosis (all forms) produced by its different manifestations

\begin{tabular}{|c|c|c|c|c|}
\hline & Hong Kong & s.D. of $\%$ & Kowloon & S.D. of $\%$ \\
\hline $\begin{array}{l}\text { Pulmonary tuberculosis } \\
\text { General tuberculosis }\end{array}$ & $\begin{array}{l}72 \cdot 95 \\
16 \cdot 64\end{array}$ & $\begin{array}{l}0 \cdot 282 \\
0 \cdot 237\end{array}$ & $\begin{array}{l}81 \cdot 21 \\
10 \cdot 05\end{array}$ & $\begin{array}{l}0 \cdot 390 \\
0 \cdot 300\end{array}$ \\
\hline $\begin{array}{l}\text { Tuberculosis of the nervous } \\
\text { system }\end{array}$ & $6 \cdot 53$ & $0 \cdot 157$ & $4 \cdot 52$ & $0 \cdot 207$ \\
\hline $\begin{array}{l}\text { Abdominal tuberculosis } \\
\text { Remaining forms }\end{array}$ & $\begin{array}{l}3 \cdot 02 \\
0 \cdot 86\end{array}$ & $\begin{array}{l}0 \cdot 109 \\
0 \cdot 059\end{array}$ & $\begin{array}{l}3 \cdot 48 \\
0 \cdot 73\end{array}$ & $\begin{array}{l}0 \cdot 183 \\
0 \cdot 085\end{array}$ \\
\hline Total number & 24769 & & 10013 & \\
\hline
\end{tabular}

in Victoria is about $2 \cdot 3$ times that of Kowloon, so that Table XXV illustrates the fact that tuberculosis mortality varies to some extent with the density of population, and Table XXVI suggests that in Hong Kong the more acute forms of the disease are more prevalent in Victoria than in Kowloon.

\section{Conclusions}

There are certain conclusions that may be drawn from the results of this survey of the mortality from tuberculosis in Hong Kong during the years 1920-34:

(1) The mortality from tuberculosis in all its forms is at least four times that of England and Wales. It may be more, for reasons mentioned in the first section. 
(2) There is no evidence that there is any tendency for this high rate to fall, nor would one expect it to do so under present conditions.

(3) All the commoner forms of tuberculosis have a disproportionately high infantile and childhood death-rate in Hong Kong as compared with Great Britain. This high rate corresponds with that met with in the early years of civil registration in England and Wales.

(4) There are reasons to justify the assumption that the mortality from tuberculosis in Hong Kong does not differ materially from that in Chinese cities.

(5) The ratio of deaths from tuberculosis to that from all causes is twice as high in Hong Kong as in England and Wales.

(6) The mortality from tuberculosis during the first 14 years of life has shown a decline during the last 15 years under review. This childhood fall is counterbalanced by a corresponding rise in the adult mortality.

(7) There is a slight tendency for more tuberculosis deaths to occur in the middle 6 months of the year than during the rest of the year.

(8) There is evidence to suggest that in Kowloon, which is not so densely populated as Victoria, there is not such a high mortality from tuberculosis as in the latter city.

Acknowledgements. I am indebted to the Hon. Dr A. R. Wellington, Director of Medical and Sanitary Services, Hong Kong, for permission to publish this paper, and I wish to thank him and Prof. L. T. Ride for their kind and helpful criticisms.

\section{REFERENCES}

Anderson, H. G. (1934). A test survey of intrathoracic tuberculosis in the Shanghai region. Chin. med. J. 48, 207-19.

- (1935). Intrathoracic tuberculosis among the Chinese, with special reference to the province of Szechuan. Tubercle, London, March, pp. 241-56; April, pp. 294-301; May, pp. 350-67.

Bume, G. F. (1933). The tuberculosis problem in China. Chin. med. J. 47, 128-37.

- (1934). The tuberculosis dispensary and its place in the control of the disease. Ibid. $48,308-18$.

California (1936). Department of Public Health. Personal communication.

ChUN, J. W. H. (1928). On the comparative frequency of non-pulmonary tuberculosis in North China. Nat. Med. J. China, 14, 245-51.

Davis, L. J. \& GUZdar, J. S. (1935). Tuberculin reactions in the Hong Kong Chinese, with special reference to the use of tuberculo-protein. J. Hygiene, Camb., 35, 300-2.

DE HAAS, J. H. (1933). Tuberculin index and pulmonary tuberculosis among Chinese infants and toddlers in Batavia. Geneesk. Tijdschr. v. Ned. Ind. 73, 898-933. Summary in Bull. Hyg. Lond. 9, 528.

DE HaAS, J. H., Sioz, K. T. \& Hong, K. T. (1933). Tuberculin index in Chinese children in Batavia. Geneesk. Tijdschr. v. Ned. Ind. 73, 934-39. Summary in Bull. Hyg. Lond. 9, 528.

GEAR, H. S. (1935a). The sex, age and monthly distribution of hospital patients in China. Chin. med. J. 49, 160-75.

(1935b). Tuberculosis in China. The incidence of the various types. Ibid. 49, 446-61.

- (1936). Disease incidence in China. Ibid. 50, 949-72. 
Gear, H. S. \& Petersen, H. (1934). Some diseases common to man and animals in China. Trans. Far East. Assoc. Trop. Med. Nanking, 2, 305.

HaLl, G. A. M. \& Chang, C. P. (1934). Latent pulmonary tuberculous infections in Chinese adults of the professional classes. Amer. Rev. Tuberc. 30, 193-208.

Korns, J. H. (1925). The incidence of tuberculous infection in China. Chin. med. J. 39, 10-19.

LAI, D. G., KAO, C. L. \& CHEN, P. N. (1934). Incidence of tuberculous infection among the Chinese of Shanghai. Ibid. 48, 750-7.

League of Nations Annual Epidemiological Report, 1936, 3, Hygiene, 3, 2.

MaCNaLty, A. S. (1932). Reports on Public Health and Medical Subjects, No. 64. Report on tuberculosis, London, H.M.S.O.

Minetr, E. P. (1930). Tuberculosis in Hong Kong. Trans. R. Soc. trop. Med. Hyg. 24, 33742.

Newsholme, A. (1923). Vital Statistics, p. 222. London.

OLDT, F. (1933). Tuberculosis in Kwangtung according to age, sex, occupation and economic condition. Chin. med. J. 47, 111-27.

Postmus, S. (1937). Health Dept. Medan, Sumatra. Personal communication.

Scotr, H. H. (1921). The prevalence and character of tuberculosis in Hong Kong. Ann. trop. Med. Parasit. 15, 227.

Statistical Review of England and Wales for 1931, Registrar-General. Tables. Part 1, Medical, 1932. H.M.S.O.

VAN DRIEL (1934). Death rates and causes of death among...estate labourers... of the Netherlands East Indies in 1931 and...1932. Medan, Sumatra.

Wellington, A. R. (1933a). Medical and Sanitary Reports for the year 1933, p. 9. Hong Kong. (1933b). Ibid. p. 45. (1934). Ibid. for the year 1934.

Wu Jur-Ping (1936). Tuberculous meningitis, a study of 200 cases. Chin. med. J. 50, 506-19.

WyLIE, J. H. (1935). Tubercular infection among Chinese middle school students. Ibid.49, 553-61.

(MS. received for publication 4. vi. 1937.-Ed.) 